\title{
The Must of Being an Individual is Correct Usage of Reason and Creative Activity
}

\begin{abstract}
As can be understood from the title of the text, a highly assertive thesis is put forward in this study. In order to justify this thesis in a philosophical sense, we first tried to reveal what the individual is, its formation and importance. The concept of the individual, which we discussed in the article and tried to describe with its indispensable conditions, refers to the individual who owes its existence to the western culture and belongs to the western civilization in terms of its characteristics. Because the must of this individual is expressed as using the reason correctly. This individual is both the creator and, because of its many characteristics, the product of a secular worldview. Trying to understand the universe, people and society, this individual acts with the patterns of his mentality and reveals his knowledge in this context. The individual is a selfconfident and independent person. The basis of the independence of a person who is conscious of being an individual consists of his loyalty to his own reason. His perception, understanding, judgment, and evaluation of reality are based on his own reason, not on the assertions of others. Since using the reason is the basic characteristic of being an individual, it is not possible to think of the individual independently of the reason and the reason of the individual. In this article, we tried to explain the nature, formation and meaning of the individual on a completely rational basis. We tried to show that the individual has to consider his own reason rather than the expectations of the society while establishing his own life in the western culture, where it is accepted that being human is synonymous with being an individual. One, who does not belong to any entity that is considered important, is a unity that believes that he lives according to his actions. The individual has a creative ability because he is unique to himself in terms of thinking and actions. In fact, the quality of creativity is the result of using the reason correctly. Being a creative person, the individual puts forward new things based on his own creative abilities. All innovations, inventions and discoveries of all kinds throughout history are the works of creative individuals. The prerequisite for creative activity is reason, and the result is honour or self-respect. Using the reason correctly is the basic virtue that is the source of all the other virtues of the individual.
\end{abstract}

Keywords: Individual, Reason, Creative Activity, Basic Virtue, Political Liberalism. 


\section{Birey Olmanın Olmazsa Olmazı Aklı Doğru Kullanmak ve Yaratıcı Etkinliktir}

Öz: Metnin başlığından da anlaşılacağı gibi bu çalışmada oldukça iddialı bir tez ileri sürülmektedir. $\mathrm{Bu}$ tezi felsefi anlamda haklı kılmak için öncelikle bireyin ne olduğunu, oluşumunu ve önemini ortaya koymaya çalıştık. Makalede ele aldığımız ve vazgeçilmez koşullarıyla betimlemeye çalıştığımız birey kavramı, varlığını batı kültürüne borçlu olan ve özellikleri itibariyle batı uygarlığına ait olan bireyi ifade etmektedir. Çünkü bu bireyin olmazsa olmazı aklı doğru kullanmak şeklinde dile getirilmektedir. Bu birey laik bir dünya görüşünün hem yaratıcısı hem de birçok özelliği itibariyle ürünüdür. Evreni, insanı ve toplumu anlamaya çalışan bu birey, sahip olduğu zihniyetin kalıplarıyla hareket etmekte ve bilgisini de bu bağlamda ortaya koymaktadır. Birey kendine güvenen ve bağımsızlık özelliğine sahip olan bir insandır. Birey olduğunun bilincinde olan insanın bağımsızlığının temeli onun kendi aklına olan sadakatinden oluşmaktadır. Onun gerçeğe ilişkin algısı, anlayıșı, yargllaması ve değerlendirmesi başkalarının öne sürümlerine değil kendi aklına dayanmaktadır. Aklını kullanmak birey olmanın temel özelliği olması nedeniyle bireyi akıldan aklı da bireyden bağımsız düşünme olanağı yoktur. Biz de bu makalede bireyin neliği, oluşumu ve anlamını tamamen rasyonel bir temele dayalı olarak izah etmeye çalıştık. İnsan olmanın birey olmakla eşanlamlı olduğunun kabul edildiği batı kültüründe bireyin kendi hayatını kurarken toplumun beklentilerinden çok kendi aklını dikkate almak zorunda olduğunu göstermeye çalıștık. Önemli olarak kabul edilen hiçbir varlığa ait olmayan birey, yapıp etmelerinde beni gereği yaşadığına inanan bir birliktir. Birey düşünme ve eylemleri açısından kendisine özgü olması nedeniyle yaratıcı bir yetiye sahiptir. Zaten yaratıcılık niteliği de aklı doğru kullanmanın sonucudur. Yaratıcı bir insan olması nedeniyle birey, kendi yaratıcı yetilerine dayanarak yeni șeyler ortaya koyar. Tarih boyunca bütün yenilikler, her türden icat ve keşifler yaratıcı bireylerin eserleridir. Yaratıcı etkinliğin ön koşulu akıl, sonucu ise onur ya da öz-saygıdır. Aklı doğru kullanmak, bireyin diğer bütün erdemlerinin kaynağı olan temel erdemdir.

Anahtar Kelimeler: Birey, Akıl, Yaratıcı Etkinlik, Temel Erdem, Siyasal Liberalizm.

\section{Introduction}

In order to explain the formation and importance of the concept of the individual, it is necessary to determine how it has been shaped in the historical process. Since this process is almost as old as the history of humanity, the effort of man to become an individual covers a long period of time. When we look at the early periods of the history of thought, we see that the existence of the society is more important than the people living there, that is, the individuals. So much so that the definition of man as a political animal did not mean that he was an individual, but that he was embedded in society as a part of a social whole (Sartori 1993: 308). The Age of Enlightenment and the French Revolution appear before us as significant turning points in the formation process of the individual. Many 
activities such as geographical discoveries, scientific developments and the translation of ancient philosophical texts from Greek and Arabic to Latin paved the way for events that would transform this period. Therefore, it can be said that the concept of the individual has become a real subject of discussion with the emergence of modern thought. Based on Descartes' subject-cantered thought, the reason came to the fore, the thought that society is more important than the individual was pushed to a secondary position, and the footsteps of an understanding that puts the individual forward began to be heard. The separation of soul and body, which Descartes accepted as two separate substances irreducible to each other, necessitated the existence of two separate worlds and laid the groundwork for the development of a secular understanding. As the individual began to gain value, the human being who exists because he thinks has been separated from the person who obeys because he believes, and the reason has become independent from belief, which prepared the causes that revealed the scientific thought and laid the foundations of a secular worldview. The humanism movement that influenced this period glorified and sanctified the human being. As a result of this, God, which was the subject matter of previous examination in the literary and philosophical works written, started to be left aside, and the subject shifted to man and his nature. In fact, this understanding of the individual formed the center of Rousseau's thoughts, who stated that human beings are too noble to serve others as a tool (Lukes 2016: 61). This idea, which glorifies man, found its most impressive and systematic expression in Kant's writings: Man, and every rational being in general, exists not only as a means for the arbitrary use of this or that will, but as an end in himself. In all his actions, whether directed at himself or directed against other rational beings, man should always be seen as an end at the same time (Kant 1997: 37).

This way of thinking has led to the idea that man can dominate everything and has revealed a human model that can dominate nature. Considering the reason as the only sacred one, this person rejected all kinds of metaphysical thought and 
prepared the environment that would create the modern scientific paradigm. In such an environment, the traditional worldview was pushed aside, and the French Revolution, which changed the course of the world, took place since each individual claimed their own rights and freedoms (Fontana, 2003: 87). According to the understanding of secular and rational individualism, which is one of the main pillars of this revolution, the right to choose has been granted only to human beings, and as an individual, a human being has the right to set his own rules and live according to it (Üskül 2003: 49). On the other hand, liberalism gave the individual the opportunity to make choices without the intervention of other people and the state, and brought the will of the individual to the fore (Nozick 1974: ix). While the understanding of the individual put forward by political liberalism was not accepted because of fascism, on the other hand, it was the target of criticism arrows of Marxism. Because Marxism proposes a transformative social process and deals with the human being with his productive side and sociality (Can 2019: 194). In addition, criticizing the understanding of freedom on which liberalism is based, Marxism sees the individual-society contradiction not as a universal phenomenon but as a product of alienated social relations within capitalism. Therefore, the fact that Marxism considers human beings not as single individuals but with their social aspects has led to the discussion of social concepts rather than the concept of individual. On the other hand, with the emergence of disciplines dealing with social problems, it is seen that the concepts of liberalism were left aside for a long time. It was necessary to wait for the twentieth century, especially the end of the world wars, for liberal individualism to come to the fore again. In the twentieth century, with liberalism, especially libertarianism, bringing the individual to the fore, the necessary conditions of being an individual were also discussed and evaluated again. 


\section{Being Individual and Rationality}

According to libertarianism, which is based on the individual and his mind, it is not possible to separate being rational from being an individual since rationality is a necessary condition of being an individual. Although the individual appears as a single entity, he is a unity. Individuum in Latin which means an indivisible whole, is the equivalent of the atom in Ancient Greek which also means indivisible, unitary. The individual emerging as itself everywhere and always with all its intensity is a reality that keeps and desires to keep itself existentially separate from everything else. The individual is in the first state of being the owner of his own actions, establishing himself with his own reason (Patterson 1953: 333), perceiving others as individuals by themselves, having his own weight, being a centre of orientation in himself from which actions are shaped, and in which everything gains value according to himself. The individual is alone in creating a life for himself and shaping his own character (Machan 2001: 79).

To be human is first and foremost to be an individual. An individual has to consider his own reason rather than the expectations of the society when deciding what kind of person he will be while establishing his own life. The individual does not belong to any entity that is considered important. People should belong only to themselves, and those who do this are considered as individuals. Because the individual's own body to nature, society, culture; In short, in all its relationships, he is a whole of life that puts its own stamp on the universe. An individual is mostly someone who lives himself as I and says that he is I. An individual is a union who believes that he lives according to self-actions (Uygur 1992: 34).

For the individual, reason is a basic quality that cannot be separated from himself (Bauman 1998: 41). There is no collective mind or collective brain anyway. Thought must be a process initiated and directed at each step by the choice of the thinking person. Because, it can be mentioned that a single individual can perceive, abstract, define and establish connections (Peikoff 1993: 198). It is impossible to 
say that a community-specific brain or a collective reason performs these operations. The reason, which is unique to the individual, not a collective mind, has the feature of creativity. Being a creative person, the individual puts forward new things based on his own creative abilities (Nehamas 2002: 330). All innovations, inventions and discoveries of all kinds throughout history are the works of creative individuals. He is the creative individual who discovered fire thousands of years ago, invented the wheel, and stands before us in the first part of every great legend that mankind has created from the beginning until today. These people took the first steps towards brand new paths, and while doing so, they had no weapon other than their own vision. Since the creative people who appeared in each age had a purpose of their own, they thought differently from each other, but they always had a common point because their way was a new way and their vision was unborrowed (Rand 1993: 678). The creative individual is not a person who acts to serve his brothers; his only reality is his own purpose. His reality is that he does what he does in his own way and succeeds. The important for him is the created thing itself; not those who use it and take advantage of it. What the creative individual created shaped that person's reality. If the creative individual had created what he had created by considering the needs of others or the purpose of serving others, what shaped that person's reality would have been the expectations and pleasures of others, not his own creation. This situation would alienate the individual or creative person from being unique.

Because of its uniqueness, the vision, strength and courage of the individual comes from his own soul. That is, those people have a unique self, and that is the whole secret of their power. That is why that power is self-sufficient, selfmotivated and self-creating. This power is in the state of a first purpose, an energy, a life force, an initiator (Can 2005: 107). The purpose of individual people is to live for themselves, not to serve others. They have achieved the things that are the crown of honour of humanity because they lived for themselves. The individual, who is aware that nothing in the world is given to him ready-made, knows that he 
has to create everything he needs. The concern of the individual, who stands alone against nature with the independent work of his mind, is to conquer nature. An individual whose basic need is independence is one who knows that one cannot work under any coercion, and that nothing new can be put forward in a place where the reason is restricted and sacrificed and subjugated to other goals and thoughts (Rand 1961: 79).

The individual is first and foremost a man of reason. He is a person who has rationality, which is the basic condition of independence and self-confidence, on which human life depends, and in all his actions, he tries to stay within the limits of what is ration. The individual is a self-confident and independent person. The basis of the independence of a person who is conscious of being an individual consists of his loyalty to his own mind (Comte-Sponville 2004: 41). His perception, understanding, judgment, and evaluation of reality are based on his own reason, not on the assertions of others. This is what intellectual independence means, and it is the foundation of being an individual. Creative people, who are individuals themselves, have always been exiled, tortured, mocked and chained in every period of history. In fact, all of these agonies have been performed on the reasons of those people, who look at the world through the eyes of living consciousness and can fulfil the vital function of establishing rational connections between events. The more these people were able to think, the more the needs of the human race were met. Thanks to those people, others were able to experience some moments where they were able to catch the spark of being human, and their survival was only possible thanks to them (Rand 1992: 678). The individual is a person who is aware that stagnation is not the destiny of humanity, that ineptitude is not human nature, that reason and intelligence are the noblest power of man. He worked continuously in service to that love of existence that only he could feel for those who plundered his labour, imprisoned him, tortured him, and he paid the price for their privileges with his own life. 
Man needs knowledge in order to survive, and he can only acquire it with his reason and be successful. People who reject the responsibilities of thinking and reason try to exist as parasites on other people's thoughts. A parasite is not an individual. An irrationalist who considers knowledge and objectivity as limitations on his freedom is not a pleasure-seeking individual who considers momentary pleasures and acts on his own feelings. The independence that the irrationalist seeks is independence from reality, a state of escape. For the irrationalist, existence is the conflict between his own desires, his own whims and the desires and whims of others, and for him the concept of objective reality has no value. It is not possible to talk about the individuality of an irrationalist person because he lives a life based on conflict and lives anomalously.

A person cannot become an individual by acting rebelliously or disproportionately, nor can he become an individual simply by rejecting collectivism and acting incongruously. A conformist person explains that as the criterion of the truth of something, 'it is true or real because others believe in its truth and reality'. A person who is an individual, on the other hand, makes a statement that "it is true and real because I know with my reason that it is true and real". Reason is the main means of human survival, and what is suitable for the life of a rational person is good, and what is inappropriate and destructive is bad. Everything that a person needs must be discovered with his reason and produced by his own effort. Ergo, the foundations of the survival of the individual are thinking and productive activity. If some people do not choose to think and live their lives based on repetition and imitation, like animals trained in routine movements and sounds learned from others, if they do not make any effort to understand their own work, their survival depends on what others think and produce. But the lives of such mental parasites, who have no knowledge of the why and for what the things others produce, is actually dependent on blind luck. Their unfocused and blurred reasons will not let them know who to imitate and whose actions are safer to follow. Those people whose reasons do not guide them in a 
right direction to follow are not individuals. If these people think that their survival depends on animal power or brute force, fraud, looting, robbery, deception, or appropriation of the labour of the people who produce, then their lives depend on their victims, and these people can never be considered individuals. Such marauding parasites try to live by destroying people who are self-sufficient for survival and act in a humane way (Rand 1964: 25).

\section{Necessary Condition of Being an Individual}

The necessary condition of being an individual is to use the reason correctly and to be creative. Creative activity is the central or basic tool of individual human life. The creative activity of the individual is a central value that determines and integrates the hierarchy of all other values. The prerequisite for creative activity is reason, and the result is honour or self-respect. Using the reason correctly is the basic virtue that is the source of all the other virtues of the individual. The main defect of man, which is the source of all his other evils, is his inability to think clearly, his consciousness is suspended; it is not blindness but the refusal to see, nor ignorance but the refusal to know. The basic virtue of being an individual is to accept reason as the source of human knowledge, to realize and accept that the only guide that will lead value judgments and actions is reason (Rawls 1999: 184). This means surrender to a conscious awareness, to reason in all of his affairs, choices and waking hours.

The individual is a person who knows what is corrupt in the world, what destroys people and nations, understands on which front the battle for survival should be fought, and sees that evil is powerless, illogical, blind and unreal. An individual is a person who knows that most of the people around him helplessly depend on his reason; he gives the victims who live in the realm of spirit and matter mystics the weapon of justice to fight against them, and is aware of how long people can survive if creative people like himself are expelled from this world (Rand 1992: 960). A creative individual is a person who has the knowledge that a 
human being can only exist by having a consciousness. It is a person who is aware that it would be a contradiction between terms to say that consciousness cannot exist if nothing exists, and that consciousness can exist without anything.

In order to live, a person must embrace three things as leading values in his life: Reason/Purpose/Self-respect. These values are also indispensable conditions of being an individual. The reason is his only means of knowledge. The end is the choice of happiness with that means. Self-respect is also an inviolable certainty that one's own reason is capable of thinking, that one's own personality is worthy of happiness. It means being worthy of life. These three values are bound up with all human good deeds and make them all necessary. All of those good deeds are as to the links between existence and consciousness. These are rationality, independence, consistency, honesty, fairness, efficiency and pride (Rand 1961: 128).

Rationality is the acknowledgment of the fact that existence exists, the affirmation that nothing can change the truth, and that nothing takes precedence over the act of perceiving it. Rationality is an uncompromising absolute. Because a concession to the irrational invalidates one's consciousness, leading to imitation of facts rather than perceiving them. To accept a mystical invention is to want existence to be destroyed, thus destroying one's consciousness. Independence, on the other hand, means understanding that the responsibility to judge is one's own and that nothing can help to get rid of it. No substitute can think for a person, no one can live someone else's life. The worst of humiliation is to let one's reason subordinate to another's, to admit that an authority is above their own, to accept as true whatever others say is true, without resorting to any criticism (Nozick 1974: 246). Just as honesty is not to falsify existence, so independence is not to deceive one's consciousness. Man cannot make a distinction between his body and his soul. To make a distinction between them is to distinguish between one's action and one's thought, which no consistent person would ever do. A person who 
distinguishes between his consciousness and his body means that he is sacrificing his own judgments to the wishes of others, which is not the characteristic of an individual who takes into account the consistency between his own thoughts and actions. A consistent person is like a judge who is not influenced by public opinion. Courage, the practical form of fidelity to existence, and self-confidence, the practical form of faithfulness to one's own consciousness, are essential qualities for the consistent man to remain true to himself. Honesty, on the other hand, can be defined as understanding that the unreal is unreal, that it cannot have any value, that neither love nor fame nor money obtained by dishonesty can be a value. Honesty is not wanting to live as an addict; especially not wanting to live dependent on the stupidity of others, or as someone whose only source of value is the idiots they can deceive. Honesty is not a social duty, nor is it a sacrifice made for the sake of others. It is the refusal to sacrifice the reality of one's own existence to the false consciousness of others. Because a person who does not sacrifice the reality of his own existence to the consciousness of others makes the choice of his ends under the direction of the reason (Branden 1964: 67).

Justice, on the other hand, is understanding that it is necessary to judge people with the same respect for reality, with the same true vision, with the most pure and rational definitions, just as we judge inanimate objects, and that every human being should be judged as he is and treated accordingly. Giving any concept a higher place than justice devalues people's moral standards, favors evil over good because only good will lose and evil will gain from failure of justice. One of the good deeds between existence and consciousness is productivity. Productivity is people's acceptance of morality and their awareness that they have chosen to live (Rand 1992: 933). Efficient work or productivity is the process by which man's consciousness controls his existence. It means constantly acquiring knowledge, shaping matter according to purpose, transforming a thought into a physical form, restructuring the world according to one's own values. Any work done with a thinking mind is creative work. There is a uniqueness of a creative activity or 
action. People who do not have their own unique activities and actions are people who have borrowed their characteristics from others. A human being without distinctive features is nothing but nonhuman features (Zijderveld 1985: 125). In a place where there is no idiosyncrasy and everything is created by a collective determination, one cannot speak of creative people and their creative actions. Although the actions of the creative person are similar to each other, there is an originality and the creation of something new or value in each of these actions. When people cheat on something beyond their reason can handle, it makes them an ape eroded by fear, fluttering through borrowed time and repeating borrowed movements. And their consent to a task below their intellect's full capacity slows the power that drives them, which condemns them to decay. People's labour is the process that will lead them to their values, and losing their passion for their values means losing their will to live.

Pride is one of the good deeds related to the bonds between existence and consciousness. Pride is the recognition of the fact that people's highest values are themselves. Like all other human values, it must be earned and deserved. Among the achievements that people can reach, there is one that will make all the others possible, and that is the creation of their own character. The characters, actions, desires and emotions of rational or creative people are always within the scope of their reasons (Uslu 2011: 113). Just as a person has to produce the physical values to maintain survival, he also has to acquire character values in order to make life worth living. Just as man is a self-created wealth, he is also a self-created soul. It needs a sense of self-worth to live, but it lacks automatic values and automatic selfesteem. In order to achieve these, he must shape his soul like a 'man', that is, like a rational being that he was born to create but can create by choice according to his own moral ideal. Evidence of reaching the stage of self-respect or self-confidence is the revulsion, trembling, and rebellion of their souls against the treacherous arrogance of sacrificing a unique value such as the consciousness of people, a unique phenomenon such as their existence, to blind loopholes, to the stagnant 
decay of others in the face of sacrificing animal status (Rand 1961: 131). An individual human is a person who is proud of his own worth and his will to live. The only moral end of this person is his own happiness, and he can achieve it only by his own values. Otherwise, neither happiness nor life can be achieved by following some irrational desires (Rand 1964: 31). The emotional state called happiness is only possible for rational people. It is possible for a person who wants nothing but rational ends, pursues rational values only, and finds his joy only in rational actions. A rational person or individual is one who supports his life with his own effort, not with robbery or charity, and who wants his happiness to come from his own success, not from the unhappiness of others or the good they will do to him. An individual does not consider his own pleasure as the purpose of others' life, just as he does not make the pleasure of others the purpose of his own life. There is no contradiction in his values, no controversy in his desires, and there is no room for any victim, no conflict of interest among people who use their reasons correctly (Rand 1992: 935).

An individual's values depend on the decisions his reason makes. Desires are not tools of knowing. In the selection of his ends, the individual is guided not by his wishes and desires, but by his thinking, which is a mental process (Rothbard 1998: 7). The individual does not consider his wishes as indispensable priorities, as if they are fate to be followed, but selects and defines his wishes through thinking, which is an operation of the reason. Unless a request is rationally validated in all conditions of his other values, ends, and knowledge, he will not act on his wish. By taking the equivalence principle as the basis of his thoughts, the individual knows that contradiction is impossible in reality and that a contradictory situation cannot succeed, and that a contradictory attempt can only lead to destruction and disaster.

Unless the individual relates any of his beliefs to the rest of his knowledge and decides what the possible conflicts are, he does not fall behind or defend any request out of context. He associates his interests with all periods of his life and 
chooses his ends accordingly. This does not mean that the individual knows everything, is not mistaken and is omnipotent. On the contrary, it means that he does not live his life on short-term accounts and is not a vagrant who acts on a spur of the moment. He does not evaluate any moment of his life by separating it from the rest. The individual is not a person who yearns for ends separated from means and surrenders himself to them. He does not defend a desire without knowing or learning about the means by which it will be accomplished. The individual does not, directly or indirectly, fall behind an end that he cannot achieve and obtain with his own efforts, and does not defend such a desire. He does not want what he does not deserve and does not pursue it. He never takes the issue out of its context on issues where the struggle is in his own interest. The individual also knows that the struggle he has given to achieve his own values includes the possibility of defeat. He also knows that there is no automatic guarantee of success in return for human effort in dealing with nature or with other people.

An individual is a person who is aware of his responsibility and does what is necessary. Most people avoid responsibility, which is a special form of intellectual obligation. It is this avoidance that is the most important reason for their failures and the futility of their efforts. In fact, what people avoid is the responsibility to evaluate the social world. They take on a ready-made world that has been given to them. At the heart of their attitude is a world they did not shape. They want to adapt themselves to the non-exhaustive demands of the people they don't know who shape that world without criticizing them. However, a person who is an individual does not shy away from any kind of intellectual responsibility, since he is aware that his own responsibility and effort are intertwined (Lévinas 1985: 100101).

As can be understood from the explanations and evaluations we have made so far, using the reason correctly and creative activity are the most basic qualities of being an individual. However, to state that these two basic qualities are 
necessary is not to claim that there are no other features in the formation of the individual. Also, the correct use of reason and the acceptance of creative activity as the necessary qualities of being an individual does not mean reducing individuality to these two qualities. The individual, of course, is not something that emerged out of blue; It is a being with historical and social characteristics. However, the point we are trying to emphasize here is the qualities that can be considered as the most important for the individual. Moreover, although every person is in the sphere of influence of a historical and social environment, not every person is considered as an individual in the sense we are talking about here. An individual is a being that can determine his existence by using the human reason correctly and selfconfidence, and is able to overcome any effect that will abolish his freedom or to put them in brackets. Therefore, the individual can take into account the existence of all kinds of historical, social and natural imperatives and open up a zone of freedom against these factors. The individual, who is aware that he is subject to physical necessity, can act freely by using his reason.

\section{Conclusion}

An individual person knows very well that all of his ends must be achieved by his own efforts, that none of the wealth, business and other human values are given to him, and that all these values can be revealed based on a rational effort. For the individual, all benefits must be the product of people's efforts, and one person's gain does not require other people's harm. For this reason, the individual does not even imagine that he has a unilaterally undeserved request on any human being, and he does not leave his own interests at the mercy of others. The individual only knows that people are irreplaceable. An individual is a person who does not surrender his reason to the wishes of others, as well as to his own feelings, passions and unreasonable wishes. An individual is a person who does not want what he does not deserve and does not look at others with cannibalistic hunger. The relationship of an individual with other people is as required by the 
structure of himself and other people, that is, through logic. Because he never wants relationships other than the ones people want to enter with their own voluntary choices. He only relates to the reasons of people, and does so for his own benefit when he sees that his interests coincide with theirs. When his interests do not coincide with those of others, he goes on his own way without engaging with them. The individual says that his gains are only through logic and that he will not surrender to anything but logic. He states that the only value people can offer him is the labor of their reasons and that there is nothing that people can benefit from their flaws, stupidity, dishonesty or fears. A society made up of people who use their reasons correctly, meaning individuals, is a free society, and in a free society there are no obstacles to people's creativity. A society formed according to the products of creative people's reasons will not leave itself under the dominance of some metaphysical powers, nor will it allow its rulers to be despots above them. It is a fact that when the management of the society falls into the hands of totalitarian and authoritarian understandings, the people who will suffer the most from this are creative people, that is, people who use their reasons correctly. It is a fact that societies cannot achieve anything by being afraid of people who use their reason, describing them as deviants and pushing them out of society, and claiming that the products they produce are contrary to traditions, customs, beliefs and customs. Just as life is an end in itself but not the means of others, man is also an end in itself and cannot be used as a means of any activity of others. Therefore, man must live for his own sake. He should not sacrifice himself to others nor should he do the vice versa. Living for one's own sake and realizing own happiness are the highest moral ends of man. The way for a person to reach such an ends passes through a free and rational society. 


\section{BIBLIOGRAPHY} Yayınları.

Bauman, Z. (1998). Postmodern Etik (çev. A. Türker). İstanbul: Ayrıntı

Branden, N. (1964). “Isn't Everyone Selfish?”, The Virtue of Selfishness, New York: New American Library.

Can, N. (2005). Özgür Birey Sinırlı Devlet. Ankara: Hece Yayınları.

Can, M. (2019). Rasyonel Bencillik Ahlakı. Ankara: Elis Yayınları.

Comte-Sponville, André (2004). Büyük Erdemler Risalesi (çev. I. Ergüden). İstanbul: İletişim Yayınları.

Fontana, J. (2003). Çarpıtılmış Geçmişe Ayna (çev. N. Elhüseyni). İstanbul: Literatür, 2003.

Kant, I. (1997). Groundwork of the Metaphysics of Morals (trans. M. Gregor). Cambridge: Cambridge University Press.

Lévinas, E. (1985). Ethics and Infinity: Conversations with Philippe Nemo (trans. by R. A. Cohen). Duquesne University Press.

Lukes, S. (2016). Bireycilik (çev. İ. Serin). Ankara: Bilim ve Sanat.

Machan, T. R. (2001). Ayn Rand, New York: Peter Lang Publishing.

Nehamas, Alexander (2002). Yaşama Sanatı Felsefesi (çev. C. Soydemir). İstanbul: Ayrıntı Yayınları

Nozick, R. (1974). Anarchy, State and Utopia. Cambridge: Basic Books.

Patterson, E. W. (1953). Jurisprudence: Men and Ideas of Law, Brooklyn: The Foundation Press.

Peikoff, L. (1993). Objectivism: The Philosphy of Ayn Rand, New York: A Meridian Book.

Rand, A. (1961). For the New Intellectual. New York: New American Library.

Rand, A (1964). The Virtue of Selfishness, New York: New American Library.

Rand, A. (1992). Atlas Shrugged. New York: New American Library.

Rand, A. (1993). The Fountainhead. New York: New American Library.

Rawls, J. (1999). A Theory Justice. Oxford: Oxford University Press.

Rothbard, M. N. (1998). The Ethics of Liberty. New York \& London: New York University Press. 
Sartori, S. (1993). Demokrasi Teorisine Geri Dönüş (çev. T. Karamustafaoğlu \& M. Turhan). Ankara: Türk Demokrasi Vakfı Yayınları.

Uslu, C. (2011). Doğal Hukuk ve Doğal Haklar. Ankara: Liberte Yayınları.

Uygur, N. (1992). İçi Dışıyla Batı́nın Kültür Dünyası. İstanbul: Ara Yayıncılık.

Üskül, Z. Ö. (2003) Bireyciliğe Tarihsel Bakış. İstanbul: Bike Yayıncılık.

Zijderveld, A. C. (1985) Soyut Toplum (çev. C. Cerit). İstanbul: Pınar Yayınları. 